ate reductase activity. Biochem. Biophys. Res. Commun., 46: 905 (1972).

19. Mudd, S. H., Uhlendorf, B. W., Hinds, K. R., and Levy, H. L.: Deranged $B_{12}$ metabolism: studies of fibroblasts grown in tissue culture. Biochem. Med., 4: 215 (1970).

20. Rosenblatt, D. S., and Erbe, R. W.: Methylene-tetrahydrofolate reductase in human cells from normals and from a family with reductase deficiency. Amer. J. Hum. Genet., 24: 65a (1972).

21. Rosenblatt, D. S., and Erbe, R. W.: Reciprocal changes in the levels of functionally related folate enzymes during the culture cycle in human fibroblasts. Biochem. Biophys. Res. Commun., 54: 1627 (1973).

22. Sato, K., Slesinski, R. S., and Littlefield, J. W.: Chemical mutagenesis at the phosphoribosyltransferase locus in cultured human lymphoblasts. Proc. Natl. Acad. Sci. U. S. A., 69: 1244 (1972).

23. Shapiro, S. K., and Ehninger, D. J.: Methods for the analysis and preparation of adenosylmethionine and adenosylhomocysteine. Anal. Biochem., 15: 323 (1966).

24. Shin, Y. S., Buehring, K. U., and Stokstad, E. L. R.: The relationships between vitamin- $B_{12}$ and folic acid and the effect of methionine on folate metabolism. Mol. Cell. Biochem., 9: 97 (1975).

25. Shin, Y. S., Williams, M. A., and Stokstad, E. L. R.: Identification of folic acid compounds in rat liver. Biochem. Biophys. Res. Commun., 47: 35 (1972).

26. Taylor, R. T., and Hanna, M. L.: Folate-dependent enzymes in cultured Chinese hamster ovary cells: Induction of 5-methyltetrahydrofolate homo- cysteine cobalamin methyltransferase by folate and methionine. Arch. Biochem. Biophys., 171: 507 (1975).

27. Amersham/Searle, Arlington Heights, Ill

28. Sigma Chemical Company, St. Louis, Mo.

29. Bellco Glass Inc., Vineland, N. J.

30. Grand Island Biological Co., Grand Island, N. Y.

31. Schwarz BioResearch, Orangeburg, N. Y.

32. Gray Industries, Inc., Fort Lauderdale, Fla.

33. Difco Laboratories, Detroit, Mich.

34. Lot 2-733, Rohm and Haas Company, Philadelphia, $\mathrm{Pa}$.

35. Omniflucr, New England Nuclear, Boston, Mass.

36. The authors gratefully acknowledge the expert technical assistance of Ann B. Georgi and Judith R. Dichter. They are indebted to Dr. J. W. Littlefield for much helpful advice in the initiation of these studies.

37. Dr. D. S. Rosenblatt is a recipient of a Postdoctoral Research Fellowship from the Canadian Cystic Fibrosis Foundation.

38. This investigation was supported by Research Grant Number HD06356, awarded by the National Institute of Child Health and Human Development, Department of Health, Education and Welfare.

39. Requests for reprints should be addressed to: D. S. Rosenblatt, M.D., MRC Genetics Group, Montreal Children's Hospital, 2300 Tupper St., Montreal H3H 1P3, Quebec (Canada).

40. Received for publication August 1, 1976

41. Accepted for publication March 9, 1977.

Pediat. Res. 11: 1141-1143 (1977)

Fibroblasts

methylenetetrahydrofolate reductase deficiency mutation

\title{
Methylenetetrahydrofolate Reductase in Cultured Human Cells. II. Genetic and Biochemical Studies of Methylenetetrahydrofolate Reductase Deficiency
}

\author{
DAVID S. ROSENBLATT ${ }^{(6)}$ AND RICHARD W. ERBE
}

Genetics Unit, Children's Service, Massachusetts General Hospital, and the Department of Pediatrics and Center for Human Genetics, Harvard Medical School, Boston, Massachusetts, USA

\section{Summary}

Methylenetetrahydrofolate (methylene- $\mathrm{H}_{4}$ PteGlu) reductase activities in extracts of both normal and reductase-deficient cells were low and quite variable during the logarithmic phase of growth. Higher activities were detected reproducibly when the cultures were confluent. Methylene- $\mathrm{H}_{4}$ PteGlu reductase activities in extracts of fibroblasts from the parents of patient $C P$ were about half of the level observed in normal control subjects. In fibroblasts from patient $C P$, the activity was $20 \%$ of normal whereas, from patients $L M$ and $B M$, the activities were $19 \%$ and $14 \%$ of normal, respectively. When incubated at $55^{\circ}$ in a solution containing all the components of the standard reaction mixture except the 5-methyl- $\mathrm{H}_{4}$ PteGlu substrate, the reductase activity in extracts of fibroblasts from two unrelated normal control subjects decreased to $31 \%$ and $22 \%$, respectively, of the initial values after $30 \mathrm{~min}$ of incubation. In contrast, the reductase in extracts of cells patient $\boldsymbol{C P}$ was rapidly and exponentially inactivated at $55^{\circ}$. The reductase activity in extracts from patients $L M$ and $B M$, the sisters, decreased to $22 \%$ and $38 \%$, respectively, of the initial values. In repeated experiments the heat inactivation of reductase activity in extracts of cells from $L M$ and $B M$ closely resembled the normal control subjects in total extent and time course of inactivation. The reductase activity in extracts from $\mathbf{W M a}$, a fourth, unreleated patient was also completely inactivated but somewhat less rapidly than with patient $\boldsymbol{C P}$. These results provide strong evidence that the reductase deficiency in these three families is due to different alleles. The data suggest that in $C P$ and WMa there is a mutationally induced structural defect in the aporeductase as the basis for the observed alteration in thermostability, presumably reflecting reduced ability to bind the FAD cofactor.

\section{Speculation}

The observation that methylene- $\mathrm{H}_{4}$ PteGlu reductase activity in crude fibroblast extracts from two of the three families studied shows reduced thermal stability as well as decreased activity raises the possibility that this enzyme is unusually susceptible to mutationally induced alterations in cofactor binding.

Methylenetetrahydrofolate reductase deficiency is an inborn error of folate metabolism in which neurologic abnormalities are accompanied by moderate degrees of homocystinemia and homocystinuria but with normal or low plasma methionine 
levels. The clinical findings in the three patients described in detail to date $(3,6,9)$ have varied, but some degree of neurologic impairment has been consistent. More recently, methylene$\mathrm{H}_{4}$ PteGlu reductase deficiency has been suspected and the diagnosis confirmed in cultured fibroblasts from a fourth $(2,10)$ and a fifth (4) patient. The specific deficiency of methylene$\mathrm{H}_{4}$ PteGlu reductase was first identified in fibroblasts $(6,9)$ and confirmed in a postmortem liver specimen from one of the patients (4). Studies by Mudd et al. (6) suggested that the residual reductase activity in fibroblasts from patient $C P$ was less stable when assayed without added flavin-adenine dinucleotide (FAD) than the reductase activities in cells from the other two patients, $B M$ and $L M$, who are sisters. We report here studies of the residual methylene- $\mathrm{H}_{4}$ PteGlu reductase activities in extracts of fibroblasts from all four patients. Our results suggest that the mutant reductase in each family is distinct. Furthermore, studies of cells from one patient and his parents suggest that methylene$\mathrm{H}_{4}$ PteGlu reductase deficiency is inherited in a Mendelian autosomal recessive pattern.

\section{MATERIALS AND METHODS}

Human skin fibroblasts were obtained from punch biopsy specimens and the cell lines were designated as follows: patient $C P$, MGF488; the parents of $C P, M G F 394$ and MGF395; patient $L M, M G F 451$; patient $B M, M G F 452$; patient $W M a$, MGF548. The procedures used were reviewed and approved by the Committee on Human Studies of each institution, and included obtaining the informed consent of the patients and/or, where appropriate, the parents. The cells were grown in roller bottles containing $100 \mathrm{ml}$ medium consisting of $85 \%$ Eagle's minimum essential medium (11) and $15 \%$ fetal calf serum (12), re-fed twice weekly. Methylene- $\mathrm{H}_{4} \mathrm{PteGlu}$ reductase activity in cell extracts was measured as described previously $(7,8)$.

\section{RESULTS}

Methylene- $\mathrm{H}_{4}$ PteGlu reductase activities in extracts of both normal and reductase-deficient cells were low and quite variable during the logarithmic phase of growth. Higher activities were detected reproducibly when the cultures had reached confluency. Therefore, measurements were made on cultures which were confluent and had been harvested 2 days after re-feeding with fresh media. Methylene- $\mathrm{H}_{4} \mathrm{PteGlu}$ reductase activities in extracts of fibroblasts from the parents of patient $C P$ were about half of the level observed in normal control subjects (Fig. 1). Fibroblasts from 10 unrelated normal control subjects yielded a mean value of $8.6 \mathrm{nmol}$ formaldehyde formed per mg protein with a standard deviation of 1.4 . The reductase activity in extracts of fibroblasts from patient $C P$ 's father was $40 \%$ of the normal mean while the mother's value was $35 \%$ of normal. In

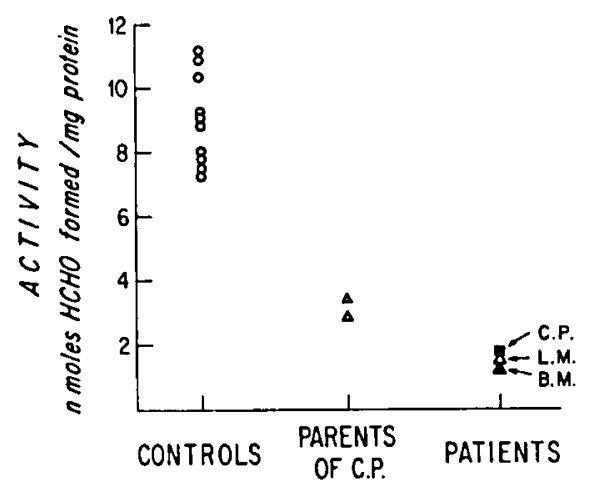

Fig. 1. Methylenetetrahydrofolate reductase activity in fibroblasts from normal control subjects, parents and patients. Each point represents cells from a separate individual and is the average of specific activities obtained in at least duplicate determinations differing by not more than $20 \%$. HCHO: formaldehyde. fibroblasts from $C P$, the reductase activity was $20 \%$ of normal, whereas from $L M$ and $B M$ the activities were $19 \%$ and $14 \%$ of normal, respectively. When equal amounts of extracts from normal and reductase-deficient cells were mixed, the total reductase activity was the sum of that in the individual cell extracts, suggesting that the reductase deficiency is not due to the presence of an inhibitor.

The $\mathrm{pH}$ activity profiles of reductase activity in extracts of cells from $C P$ and $L M$ gave relatively narrow curves with maximal activities near pH 6.3 as in the control subjects (data not shown). Preliminary kinetic studies of reductase activity in the crude extracts showed no consistent alterations in the apparent $\mathrm{K}_{\mathrm{m}}$ for 5-methyl- $\mathrm{H}_{4} \mathrm{PteGlu}$ in cells from $C P$ and $L M$. However, the low reductase activities in the reductase-deficient cells and the variability of the measured activities at low substrate concentrations precluded more precise studies.

The thermal stabilities of methylene- $\mathrm{H}_{4} \mathrm{PteGlu}$ reductase activity from the deficient cells were compared to normal subjects (Fig. 2). When incubated at $55^{\circ}$ in a solution containing all components of the standard reaction mixture except the FAD cofactor and the 5-methyl- $\mathrm{H}_{4} \mathrm{PteGlu}$ substrate, the reductase in fibroblast extracts was almost entirely inactivated within $5 \mathrm{~min}$ (Fig. $2 A$ ), the reductase from the normal subjects being less rapidly inactivated than the residual reductase from the patients' cells. However, when incubated under these conditions but in the presence of $72 \mu \mathrm{M}$ FAD, varying degrees of cofactor stabilization were clearly seen (Fig. $2 B$ ). The reductase activity in extracts of fibroblasts from two unrelated normal control subjects decreased to $31 \%$ and $22 \%$, respectively, of the initial values after $30 \mathrm{~min}$ of incubation. In contrast, the reductase in extracts of cells from patient $C P$ was rapidly and exponentially inactivated at $55^{\circ}$. The reductase activity in extracts from patients $L M$ and $B M$ (the sisters), decreased to $22 \%$ and $38 \%$, respectively, of the initial values. In repeated experiments the heat inactivation of reductase activity in extracts of cells from $L M$ and $B M$ closely resembled the normal control subjects in total extent and time course of inactivation. The reductase activity in extracts from $W M a$, a fourth, unrelated patient, was also completely inactivated but somewhat less rapidly than with patient $C P$. The same pattern of inactivation was obtained with extracts that had been freed initially of low molecular weight substances by gel filtration (Sephadex G-25 in $30 \mathrm{mM} \mathrm{K}$ phosphate, $\mathrm{pH} 6.3$ ).
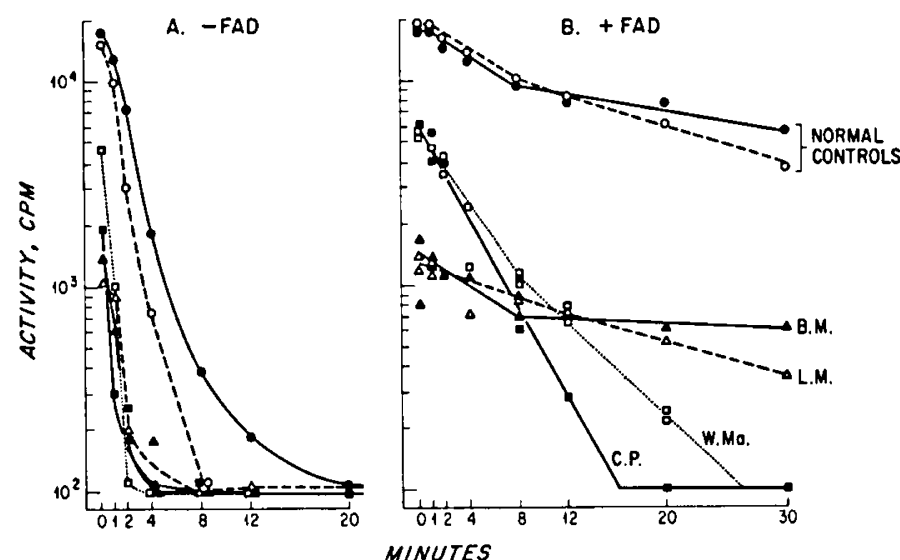

Fig. 2. Thermal stability of methylenetetrahydrofolate reductase activity. Extracts of fibroblasts containing $0.3-0.6 \mathrm{mg}$ protein were added to a solution without FAD $(A)$ or with $72 \mu \mathrm{M}$ FAD $(B)$ containing all other components of the standard reaction mixture except substrate. After incubation at $55^{\circ}$ for the time indicated, the reaction tubes were returned to the ice bath, the $\left[5{ }^{14} \mathrm{C}\right]$ methyltetrahydrofolate substrate was added and, after incubation at $37^{\circ}$ for $60 \mathrm{~min}$, the reactions were terminated and the product measured as described previously (7). Activity is expressed as counts per min of formaldehyde formed per reaction mixture. 
In additional experiments (data not shown), when $72 \mu \mathrm{M}$ FAD was added to the reaction mixtures after the $55^{\circ}$ preincubation but prior to assay, the reductase activities observed were unchanged, indicating that the FAD cofactor is not able to reactivate the reductase.

\section{DISCUSSION}

The specific activities of methylene- $\mathrm{H}_{4} \mathrm{PteGlu}$ reductase in extracts of confluent fibroblasts from patients $C P, L M$, and $B M$ were well below normal when assayed under standard conditions as has been reported previously by Mudd et al. (6), Shih et al. (9), and Freeman et al. (3). The expression of the deficiency in fibroblasts from these patients and the fact that methylene$\mathrm{H}_{4} \mathrm{PteGlu}$ reductase activity is easily detected in normal amniotic fluid cells (7) raise the possibility that this disorder can be diagnosed prenatally. Fibroblasts from the parents of $C P$ yielded reductase activities intermediate between those of $C P$ and the normal control subjects, suggesting autosomal recessive inheritance of this inborn error of folate metabolism. We have no explanation for the fact that these presumably heterozygous values were reproducibly less than half of the normal mean. Although in the present studies the culture conditions used were those that yield reproducible values, it is important to note that the reductase activity normally fluctuates by 2.5 -fold or more depending on the stage of cell growth, being lowest in the logarithmic phase and highest deep in confluency (7). If uncontrolled, these growth-related fluctuations could produce an erroneous diagnosis of heterozygous reductase deficiency.

Although the omission of FAD from the standard assay reaction mixture at $37^{\circ}$ did not affect the reductase specific activity in extracts of normal fibroblasts $(6,7)$, the reductase activity was much less stable at elevated temperatures in the absence of added FAD than when $72 \mu \mathrm{M}$ FAD were added (Fig. 2). This presumably represents cofactor stabilization through formation of an enzyme-FAD complex, as originally postulated by Donaldson and Keresztesy (1).

Although the $\mathrm{pH}$ optimum and $\mathrm{K}_{\mathrm{m}}$ for 5-methyl- $\mathrm{H}_{4} \mathrm{PteGlu}$ of the residual methylene- $\mathrm{H}_{4} \mathrm{PteGlu}$ reductase activity in the two patients tested were normal, the thermostabilities differed greatly. When incubated at $55^{\circ}$ in the presence of $72 \mu \mathrm{M}$ FAD (Fig. 2), two slopes of inactivation were apparent in extracts from two unrelated normal control subjects and inactivation was only partial in the 30 -min test period. Although the specific reductase activities were reduced in all patients, the residual reductase activity in patients $L M$ and $B M$ was similar to normal in regard to both the degree of inactivation and the biphasic time course. The reductase in patient $C P$ was least thermostable and was inactivated with a single exponential slope, whereas the reductase in WMA was inactivated at an intermediate biphasic rate. Thus the two normal subjects and the two sisters, $L M$ and $B M$, show consistent patterns of inactivation in the presence of added FAD, whereas the two other unreleated patients, $C P$ and $W M a$, are distinctly different. These results provide strong evidence that the reductase deficiency in these three families is due to different alleles. In all three families the mutations have decreased the catalytic capacity and/or the total amount of methylene- $\mathrm{H}_{4}$ PteGlu reductase. However, in $C P$ and, to a lesser extent, in $W M a$, the interaction with FAD has also been affected. No evidence has been published to indicate whether mammalian methylene- $\mathrm{H}_{4}$ PteGlu is composed of subunits. Purification of the normal and mutant reductase proteins would probably be a prerequisite to more detailed studies on the molecular basis of reductase deficiency. Furthermore, too little information is presently available regarding the relevant conditions in vivo to know what role this altered thermostability might play in the clinical and metabolic manifestations of the methylene- $\mathrm{H}_{4}$ PteGlu reductase deficiency in these patients.

Mudd et al. (6) first suggested that the specific genetic lesion in $C P$ might be different from that in the sisters and raised the possibility that the reductase activity in $C P$ might be unstable when assayed without FAD, although the possibility of a primary abnormality in flavin metabolism was not ruled out. The data presented here strongly suggest that in $C P$ and $W M a$ there is a mutationally induced structural defect in the aporeductase as the basis for the observed alteration in thermostability, presumably reflecting reduced ability to bind the FAD cofactor. Thus the methylene- $\mathrm{H}_{4} \mathrm{PteGlu}$ reductase deficienty, detected to date in three unrelated families, results from at least three distinct mutant alleles.

\section{CONCLUSION}

Methylene- $\mathrm{H}_{4}$ PteGlu reductase activity in crude extracts of four patients in three families with a deficiency of this enzyme ranged from 14-20\% of normal. The activities in extracts from the parents of one patient were $40 \%$ and $35 \%$ of normal, suggesting that this inborn error of metabolism is inherited in an autosomal recessive pattern. Thermal stability studies demonstrated a different pattern of heat inactivation in each of the families, which suggests that the reductase deficiency in these unrelated families results from at least three distinct mutant alleles.

\section{REFERENCES AND NOTES}

1. Donaldson, K. O., and Keresztesy, J. C.: Naturally occurring forms of folic acid. II. Enzymatic conversion of methylenetetrahydrofolic acid to prefolic A-methyltetrahydrofolate. J. Biol. Chem., 237: 1298 (1962).

2. Erbe, R. W.: Inborn errors of folate metabolism. N. Engl. J. Med., 293: 753, 807 (1975)

3. Freeman, J. M., Finkelstein, J. D., and Mudd, S. H.: Folate-responsive homocystinuria and "schizophrenia." A defect in methylation due to deficient 5,10-methylenetetrahydrofolate reductase activity. N. Engl. J. Med., 292: 491 (1975).

4. Kanwar, Y. S., Manaligod, J. R., and Wong, P. W. K.: Morphologic studies in a patient with homocystinuria due to 5,10 -methylenetetrahydrofolate reductase deficiency. Pediat. Res., 10: 598 (1976).

6. Mudd, S. H., Uhlendorf, B. W., Freeman, J. M., Finkelstein, J. D., and Shih, V. E.: Homocystinuria associated with decreased methylenetetrahydrofolate reductase activity. Biochem. Biophys. Res. Commun., 46: 905 (1972).

7. Rosenblatt, D. S., and Erbe, R. W.: Methylenetetrahydrofolate reductase in cultured human cells. I. Growth and metabolic studies. Pediat. Res. 11: 1137 (1977).

8. Rosenblatt, D. S., and Erbe, R. W.: Reciprocal changes in the levels of functionally related folate enzymes during the culture cycle in human fibroblasts. Biochem. Biophys. Res. Commun., 54: 1627 (1973).

9. Shih, V. E., Salam, M. Z., Mudd, S. H., Uhlendorf, B. W., and Adams, R. D.: A new form of homocystinuria due to $\mathrm{N}^{5,10}$-methylenetetrahydrofolate reductase deficiency. Pediat. Res., 6: 395 (1972).

10. Tibbles, J. A. R.: Manuscript in preparation.

11. Grand Island Biological Co., Grand Island, N. Y.

12. Gray Industries, Inc., Fort Lauderdale, Fla.

13. The authors gratefully acknowledge the expert technical assistance of Judith R. Dichter, Ann B. Georgi, Nora Vera, and Angela Pottier. They are indebted to Dr. J. W. Littlefield for much helpful advice in the initiation of these studies.

14. Dr. D. R. Rosenblatt is a recipient of a Postdoctoral Research Fellowship from the Canadian Cystic Fibrosis Foundation.

15. This investigation was supported by Research Grant Number HD06356, awarded by the National Institute of Child Health and Human Development, Department of Health, Education and Welfare.

16. Requests for reprints should be addressed to: D. S. Rosenblatt, M.D., MRC Genetics Group, Montreal Children's Hospital, 2300 Tupper St., Montreal H3H 1 P3, Quebec (Canada).

17. Received for publication August 1, 1976.

18. Accepted for publication March 9, 1977. 